\title{
VALIDATION OF THE CONDENSATION PARTICLE COUNTER UF- 02M IN LABORATORY AND AMBIENT CONDITIONS
}

\author{
G. Mordas, V. Ulevicius, K. Plauškaitè, and N. Prokopčiuk \\ State Research Institute Center for Physical Sciences and Technology, Savanoriu 231, LT-02300 Vilnius, Lithuania \\ E-mail: genrik@ftmc.lt
}

Received 19 February 2013; revised 16 April 2013; accepted 20 June 2013

\begin{abstract}
The main performance characteristics of the modernized condensation particle counter (CPC) UF-02M were determined. We studied the particle number concentration range of the instrument and the detection efficiency as a function of the particle diameter experimentally. In order to determine a cut-size $D_{50}$, the function was fitted to the experimental data. According to the fitting, the cut-size was $4.35 \mathrm{~nm}$. The determined cut-size allows detecting the aerosol particles of the nucleation mode, giving possibilities to find many applications of the CPC UF-02M in the investigations of the aerosol nanometre particle dynamical properties. The counting efficiency of the CPC at high particle concentrations was experimentally investigated using silver particles of a $20 \mathrm{~nm}$ diameter. The minimum measured number concentration of aerosol particles was $0.003 \mathrm{~cm}^{-3}$, the maximum was $150000 \mathrm{~cm}^{-3}$ with the accuracy of $20 \%$. The operation of the CPC UF-02M was compared with the operation of a commercially available SMPS TSI3936 under ambient conditions. The measured number concentrations were comparable with 5\% accuracy. During the testing time, both instruments detected a new particle formation event. It was determined that the number concentration measured with the modernized CPC was higher than that determined by the SMPS. It was explained that a new CPC had a lower cut-size and detected smaller particles than the SMPS did.
\end{abstract}

Keywords: condensation particle counter, detection efficiency, nanoparticle

PACS: 92.60.MZ, 92.20.Bk

\section{Introduction}

The number concentration of aerosol particles of nucleation mode are measured using condensation particle counters (CPCs). A working principle of CPCs comprises three consecutive processes: supersaturating aerosol-laden air with vapour of a working fluid, growth of the particles by condensation of the supersaturated vapours, and optical detection of the particles after their growth. The CPCs are classified according to the technique used in creating supersaturation: adiabatic expansion of an aerosol-vapour mixture [1], thermal diffusion [2], and mixing of cool and warm saturated air flows [3, 4]. The widely used commercial CPCs (TSI3010, TSI3022, TSI3025, TSI3007) are conductive cooling instruments, and all these instruments use alcohol to create supersaturation [5]. The instruments were investigated by many authors and their performance characteristics were published [6] 8 ]. The modernized CPC versions appeared on the market in the last decade. New modernized CPC characteristics were examined and generalized by Mordas et al. [9].

Last year, the instrument modernization was done not only for an alcohol-based CPC, but a new supersaturation creating technique was developed by Hering and Stolzenburg [10, 11]. A new unique design of the CPC allows using water as a working fluid. The first produced water-based CPC (TSI3785) was described and investigated by several researchers [12-14] to detect ultrafine aerosol particles. The WCPC was later modified by manufacturers and a new ultrafine water-based CPC 
TSI3786 was constructed. It is a thermally diffusive, continuous, laminar-flow laminar CPC. The condensational growth of the particles is achieved by heating the aerosol flow in a wetted growth tube. Due to the fact that mass diffusivity of water is higher than thermal diffusivity of air, a supersaturated area is generated inside the growth tube. Thus, the created supersaturated conditions allow promoting a condensational growth of passed particles. The diffusion losses of ultrafine particles are minimised by transporting an aerosol flow to the growth tube through a special capillary and focusing it in the centreline of the growth tube. That determined perfect instrument performance characteristics [14].

The most important characteristic of condensation particle counters is the detection efficiency as a function of the particle size, but a more practical parameter is the cut-size $D_{50}$ - a diameter at which the detection efficiency drops to $50 \%$. The cut-size $D_{50}$ depends on aerosol transport losses in the inlet of the CPC, registration efficiency of the optical system, and particle activation efficiency in the CPC condenser. Stoltzenburg and McMurry [15] showed that the cut-size mostly depended on supersaturation conditions in the CPC condenser. The conditions are determined according to the temperature of the saturator, the temperature of the condenser, the volatility properties of the condensed material, and the aerosol flow rate [15]. Thus, different type CPCs can be compared with each other using the experimentally determined cut-size $D_{50}$.

The CPCs measure the total number concentration of the aerosol particles, which are larger than the CPC cut-size $D_{50}$. The measured total number concentrations are from several hundred (in the polar cycle environment [16]) to a million particles per cubic centimetre (in the urban environment [17]). Thus, the application of CPCs in different studies is dependent on the instrument counting efficiency. The counting efficiency determines the $\mathrm{CPC}$ measured concentration range.

In this paper, we investigate the main performance characteristics of the modernized CPC UF-02M. The study includes the tests of stability of working characteristics of the instrument, the determination of the CPC detection efficiency and the cut-size $D_{50}$ for silver aerosol particles, and the investigation of the instrument counting efficiency concluding the minimal and maximum meas- ured number concentrations. In addition, the CPC UF-02M was operated with the commercial SMPS TSI3786 under ambient conditions. The measured total particle number concentrations were compared during a new particle formation event.

\section{Methods}

The operation of a condensation particle counter relies on the activation of sampled aerosol particles to optically detectable sizes. The smallest observable particle size, i. e. the cut-off size of the CPC, is determined as a size where $50 \%$ of incoming particles are successfully accounted for. This is the most important parameter, which determines the suitability of a given condensation particle counter for a particular purpose. In this study, the detection efficiency $D_{50}$ is determined experimentally for a new condensation particle counter UF-02M using the measurement method presented in Scheibel and Porstendörfer [18]. A scheme of the calibration instrumentation is presented in Fig. 1 .

The particles generated in gas by heating bulk material with a tube furnace and followed by cooling are formed by nucleation of the produced vapours. The size and number concentration of the produced particles depend on evaporated material, heating and cooling temperatures, and the flow rate through the furnace in which the temperature was $1100 \pm 50{ }^{\circ} \mathrm{C}$. The evaporated material was silver, which is used as a standard material for CPC calibration. The flow rate of nitrogen passed through the tube was set at $3.2 \mathrm{l} / \mathrm{min}$. In this environment, polydisperse aerosol particles of silver material were produced. The generated particle size distribution is illustrated in Fig. 2 .

The polydisperse aerosol formed in the tube was charged with the ${ }^{241} \mathrm{Am}$ bipolar charger and classified using a differential mobility analyser (DMA VIE-08, Hauke, length $10.9 \mathrm{~cm}$ ). The DMA was operated using the aerosol flow rate of $2.01 / \mathrm{min}$ and the sheath and excess air flow rates of $20.0 \mathrm{l} / \mathrm{min}$. All flows in the experimental set-up were controlled using needle valves. The calibration of flows was done using a bubble flow metre (Sensidyne Gilibrator2).

The exited monodisperse aerosol was diluted with clean air to reduce the aerosol concentration below $10^{4} \mathrm{~cm}^{-3}$. The diluted sample was directed to the CPC UF-02M and the TSI3068 aerosol 


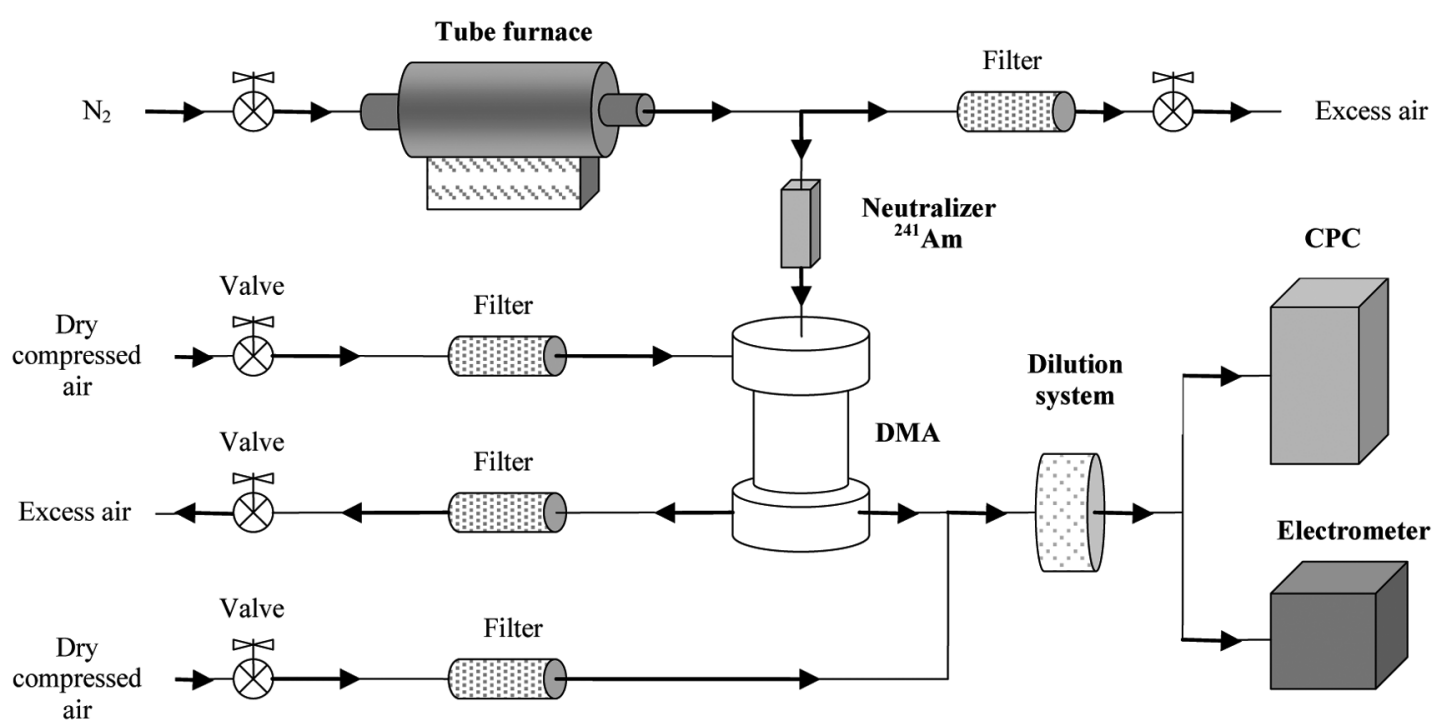

Fig. 1. Experimental set-up for determination of $\mathrm{CPC}$ detection efficiency and particle number concentration range.

electrometer. It allows decreasing the coincidence problem in the optical system of the CPC. Thus, the particle number concentration measurement accuracy did not exceed $2 \%$.

The detection efficiency was determined as the ratio of the particle number concentration measured with CPC to the particle number concentration determined with the aerosol electrometer. Since the generated particles in this study were less than $30 \mathrm{~nm}$ in diameter, they were most probably singly charged [19]. This justified the use of an electrometer as a reference instrument.

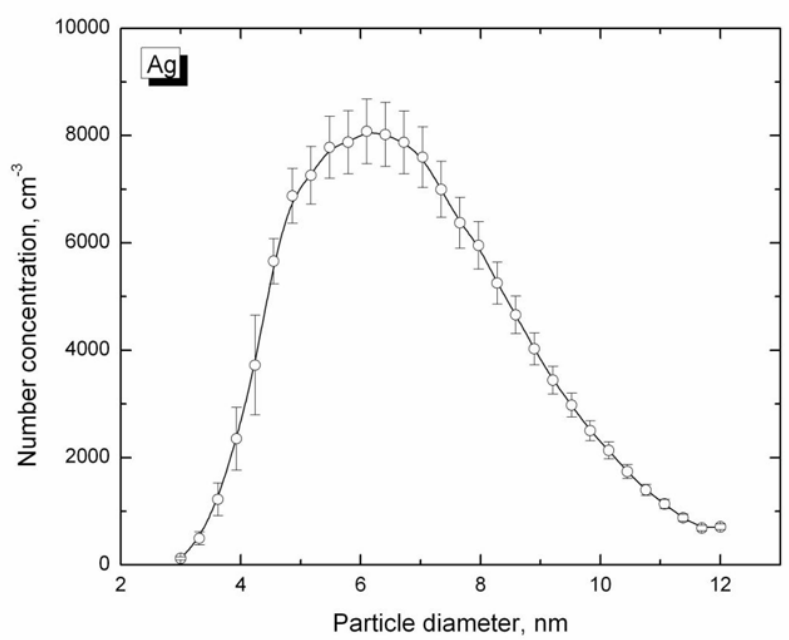

Fig. 2. Number concentration of generated silver particles as a function of particle diameter during our laboratory measurements.
Using the same experimental set-up, the concentration calibration was performed. The measured concentration values of the CPC UF-02M and the TSI3068 electrometer were compared. The measured concentration range of the certificated electrometer was from $10^{2}$ to $10^{7} \mathrm{~cm}^{-3}$. That allows calibrating the CPC and determining the maximum concentration limit of the counter.

The CPC UF02 was compared with the scanning mobility particle sizer (SMPS) (TSI Inc. SMPS model 3936 [20]). Both instruments were installed at the atmospheric research station in Preila, Lithuania. They were sampling ambient air of the coastal environment. The comparison experiment was performed during May 2011.

\section{Results and discussions}

\subsection{Working characteristics of the CPC UF-02M}

The performance of a CPC in a long run crucially depends on the design of the instrument. The developed CPC design was described in an EU patent [21]. Later, the instrument was modified: the fan geometry was changed, the used flows were fixed by needle valves, and the temperature of the condenser was stabilised with a new electronic cooling system. The reliability of the particle detection rests on the stability of the temperature gradients established inside the CPC. Furthermore, the optical system counting the particles as well as the 
attached electronics should be produced with great care in order to successfully observe particles with a rather large concentration range. In addition, the flow system has to deliver the aerosol sample first to the supersaturated region, where the particles are activated. The activated droplets have to be then efficiently transported to the optical detection unit. During transportation the particle losses have to be minimised. As a result, the modified instrument is distinguished for new performance characteristics.

The characteristics of a UF-02M swirling flow condensation particle counter are investigated in this study. The modified instrument was operated during one hour in the conditioned room where room temperature was $20.0 \pm 0.5^{\circ} \mathrm{C}$ and relative humidity was $45 \pm 5 \%$. Operating under such conditions, the instrument working characteristics were examined. The temperatures of the saturator and the condenser were monitored with built-in temperature sensors (Dallas, DS1626). The measured temperatures were $43.0 \pm 0.1^{\circ} \mathrm{C}$ and $10.0 \pm 0.1{ }^{\circ} \mathrm{C}$ for the condenser and the saturator, respectively. Fluctuations of both temperatures were smaller than $1 \%$. The temperature of the optics had the strongest variation of $2 \%$ due to the fact that the pulsed laser generated a fluctuating heat load to the system. The stable temperatures inside the CPC provided a well-controlled supersaturation inside the condenser. This provided a reliable and repeatable growth of the sampled particles, which were introduced to the counting optics with a steady flow rate. The used aerosol flow rate was determined to be $274.9 \pm 0.9(0.3 \%) \mathrm{cm}^{3} / \mathrm{min}$. Also, the sheath flow through the saturator was $253.2 \pm 0.6(0.2 \%)$ $\mathrm{cm}^{3} / \mathrm{min}$. The calibrated total flow rate was $1994 \pm 4(0.2 \%) \mathrm{cm}^{3} / \mathrm{min}$. Thus, the flow mixing ratio was 0.92 . So, the flow stability was guaranteed with the accuracy of $0.3 \%$. The assembly of improvements and determined working characteristics allow concluding that the instrument provides conditions for a constant growth of aerosol particles in the supersaturated environment.

\subsection{Particle number concentration range}

One of the main performance characteristics of a $\mathrm{CPC}$ is the range of concentration measured with the instrument. It determines the field of instrument applications. So, measuring low concentra- tion, a CPC can be used in different mobility particle analysing systems. Traffic pollution analysers need to have a device to measure high particle concentrations. In each case, different optical particle detection schemes are used. The low concentration measuring devices use a single particle counting method. For high concentration, a photometric method is applied. In our case, the single particle counting system is installed in the CPC UF-02M. The system detects the light scattered by the single particles and converts it to a single short electrical pulse. All pulses are counted electronically during a measurement period (1s). Then, the measured pulse number is recalculated to the particle number concentration. Thus, the CPC UF-02M can measure a very low particle concentration. However, at a high particle concentration, the pulse width increased due to coincidence of the electrical pulses. This is a result of multiple particles present in a measurement volume of a laser beam. The particles are incorrectly counted as one single particle. Thus, the determination of particle coincidences was needed. The calculation results show that for concentration of $1000 \mathrm{~cm}^{-3}$, the pulse coincidence is smaller than $1 \%$. However, at $10000 \mathrm{~cm}^{-3}$ it is already (as) $11.75 \%$. It is higher than $50 \%$ for concentrations higher than $50000 \mathrm{~cm}^{-3}$. Thus, coincidence increased exponentially as a function of the aerosol number concentration after the concentration of $10000 \mathrm{~cm}^{-3}$. To eliminate this problem, a lifetime counting method was included in the concentration calculation algorithm. This broadened the concentration measurement range up to $10000 \mathrm{~cm}^{-3}$. The algorithm was installed in the microprocessor of the CPC and it was used to calculate the particle number concentration in all concentration ranges. Using it, the measured concentration range was corrected automatically by the CPC. The minimum and maximum of the measured aerosol particle number concentration were investigated.

The minimum detectable number concentration is determined by the false background counts in the optics. For these investigations, a HEPA filter was connected into the inlet of the CPC. The concentrations were measured during one hour. The average number concentration of aerosol particles during the measurement period was calculated. The results show that when the difference of temperatures was $33.0^{\circ} \mathrm{C}$, the false background was 
only $0.003 \mathrm{~cm}^{-3}$. The existence of this background can be explained by a particle production due to homogeneous or ion-induced nucleation inside the CPC or by the noise of the electronics.

The maximum number concentration of the aerosol particles measured with the CPC UF-02M was investigated comparing the values measured with the CPC to those of the electrometer. The experiments were performed for monodisperse silver particles of a $20 \mathrm{~nm}$ diameter. The results of a series of measurements are shown in Fig. 3 . Relatively large fluctuations in the ratio between the concentrations of the two instruments are observed for concentrations below $3000 \mathrm{~cm}^{-3}$ and the best correlation is in the concentration range from 3000 to $80000 \mathrm{~cm}^{-3}$. For aerosol particle concentrations higher than $80000 \mathrm{~cm}^{-3}$, the concentration measured with the CPC UF-02M is lower than the concentration measured with the electrometer. The measurement accuracy is higher than $20 \%$ for concentrations higher than $150000 \mathrm{~cm}^{-3}$. At a higher particle concentration, the coincidence increases exponentially as a function of the particle concentration, and the measurement accuracy decreases. Thus, the device cannot be used to measure aerosol number concentration larger than $150000 \mathrm{~cm}^{-3}$ accurately.

The same measurements were conducted for the temperature differences between the saturator and condenser of the UF-02M. The experiment results showed that no influence of the temperature difference on the maximum measured num-

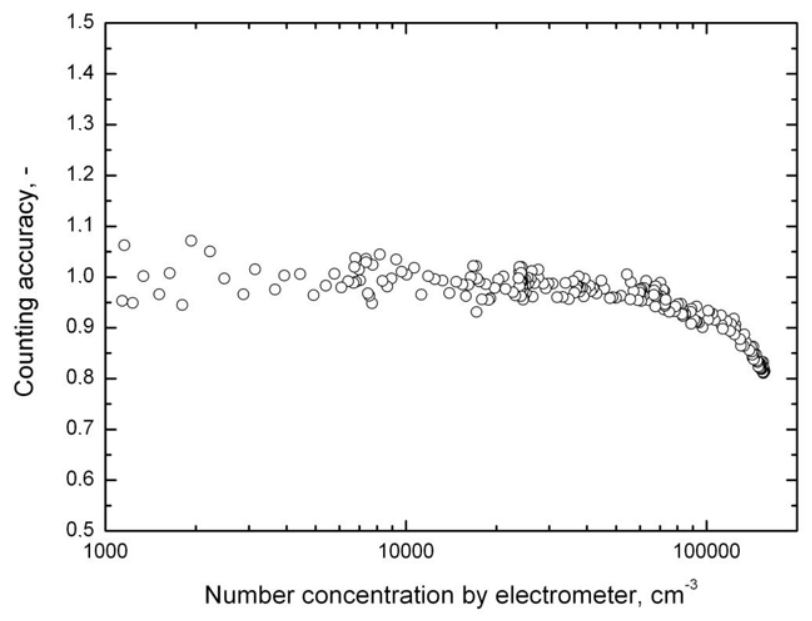

Fig. 3. Counting accuracy of the CPC UF-02M as a function of particle number concentration. ber concentration was observed. Thus, all particles grew to the optical detectable size (up to $0.3 \mathrm{um}$ ).

\subsection{Detection efficiency}

The limited detectable particle diameter of an optical counter is $0.1-0.5 \mathrm{um}$. Smaller particles cannot be measured using optical methods. However, the developed technologies of the CPC allow magnifying the aerosol particles in size by condensing a supersaturated gas on the particle surface. Grown particles are detectable with the optical system. However, the particle growth process depends on the condensed material properties, supersaturation level, and aerosol flow. All these parameters determine the instrument detection efficiency. In this study, we investigated the CPC UF-02M detection efficiency using an experimental set-up. The experimental results are presented in Fig. 4 .

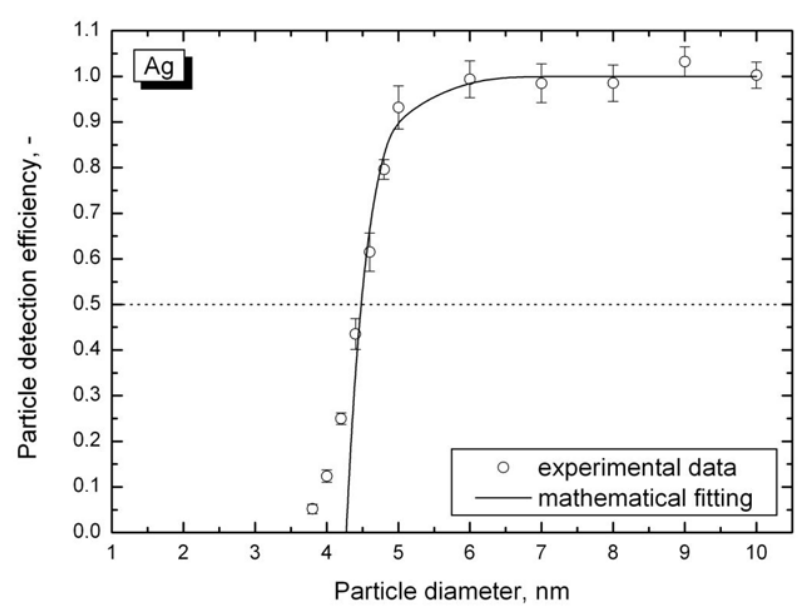

Fig. 4. Particle detection efficiency of the CPC UF-02M as a function of particle size determined for silver particles.

It shows the ratio between concentrations of UF-02M and a reference electrometer is presented as a function of a particle diameter. The detection efficiency reached the value of 1 at particle sizes larger than $6 \mathrm{~nm}$. The detection efficiency decreases rapidly and is smaller than 0.1 for particles below $4 \mathrm{~nm}$ in diameter. The result shows that the detection efficiency curve is very steep providing a well-defined smallest observable size.

In order to determine a cut-size, i. e. the particle size when $50 \%$ of the particles were counted, a 
function was fitted to the experimental data. The function had a form

$$
E(D)=1-\frac{\lambda_{1}}{1+\mathrm{e}^{\left(D-\lambda_{2}\right) \lambda_{3}}},
$$

where $D$ is the particle diameter, $\lambda_{1}=5.0, \lambda_{2}=3.65$, and $\lambda_{3}=0.32$ are empirical parameters determined based on the least-squares fitting. According to the fitting, the cut-size $D_{50}$ was $4.35 \mathrm{~nm}$. Thus, the determined instrument cut-size of $4.35 \mathrm{~nm}$ allows detecting the aerosol particles of the nucleation mode. It gives possibilities to find many applications of the CPC in the investigations of the aerosol nanoparticle dynamical properties [22].

\subsection{Ambient aerosol measurements}

A comparison experiment of the CPC and the SMPS was performed under ambient conditions during May 2011. The SMPS registered a new particle formation event, when new particles appeared as a result of the gas-particle processes [23]. This process is well illustrated by the variation of the measured particle number size distribution in Fig. 5. It can be seen that during the night-time there were only particles of the Aitken mode in the air. Their pick size was at $80 \mathrm{~nm}$. There were no particles of the nucleation mode, and a low concentration $\left(<1000 \mathrm{~cm}^{-3}\right)$ of the accumulation mode particles was observed. Close to sunrise at 4:30 a.m., the particle number concentration of Aitken and nucleation modes increased shortly. At 6:00 a.m., a new particle formation event was seen during the
SMPS measurements: the number concentration of the nucleation mode particles increased rapidly. The number concentration was measured to be increasing for several hours (Fig. 6). While growing, the appearing particles increased in size increasing the number concentration of Aitken and accumulation mode particles. As a result, the total number concentration increased as well. This dynamical process is illustrated in Fig. 6. During the experiment, the instruments were operating at the particle concentration between 1000 and $16000 \mathrm{~cm}^{-3}$. The measurement results of two instruments are seen to agree rather well (with the accuracy of 5\%).

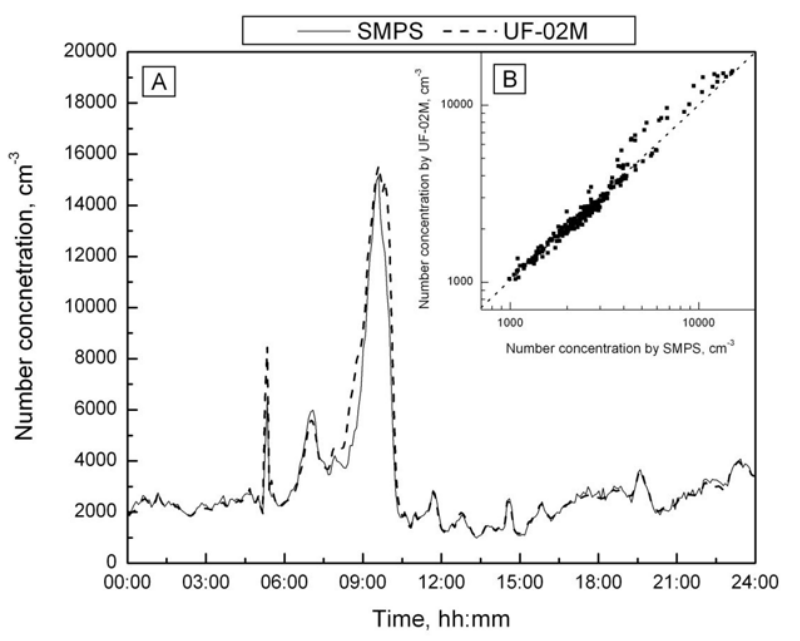

Fig. 6. Comparison of the total measured number concentration with CPC UF-02M and SMPS TSI3936 during 7 May 2011: (A) time variation of the total particle number concentrations, (B) relationship between measured concentrations.

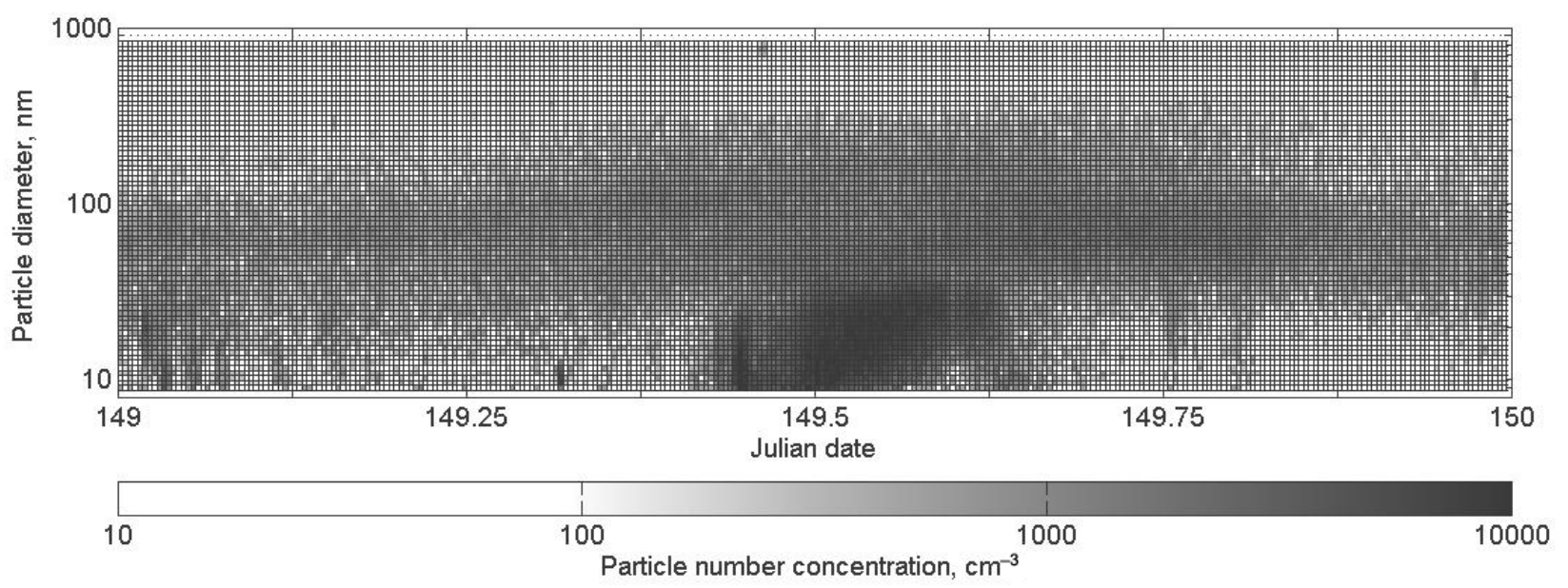

Fig. 5. Particle number size distribution during a new particle formation event on 7 May 2011 stated on measurements of the SMPS model 3936. 
However, during a new particle formation event, the CPC UF-02M measured a higher particle number concentration than the SMPS system did. It can be explained by the fact that the CPC UF-02M had a lower cut-size. This is important when new particles of the nucleation mode are formed.

\section{Conclusions}

The main working characteristics (the temperature of the saturator, the temperature of the condenser, and the operating flow rates) of the CPC UF-02M were studied. The studies showed that the saturator's temperature was $43.0 \pm 0.1{ }^{\circ} \mathrm{C}$, and the condenser's temperature was $10.0 \pm 0.1{ }^{\circ} \mathrm{C}$. The operating flow rates were calibrated with the needle valves increasing the flow stability. The fluctuations of temperatures were only $0.1{ }^{\circ} \mathrm{C}$; the flow rates were fixed with $0.3 \%$ accuracy. The stability of the instrument working characteristics allows improving the instrument detection efficiency. The particle detection efficiency of the CPC UF-02M was experimentally investigated in a 3-10 $\mathrm{nm}$ particle diameter range. The cut-size $D_{50}$ was determined by fitting the mathematical function to the empirical data and it was $4.35 \mathrm{~nm}$. The experiment was performed using silver as the particle material.

The measured particle number concentration range was experimentally investigated using $20 \mathrm{~nm}$ particles. It was determined that the minimum detectable particle number concentration was $0.003 \mathrm{~cm}^{-3}$, and the maximum was $150000 \mathrm{~cm}^{-3}$ with the accuracy of $20 \%$. It allows stating that the CPC can be effectively used in clean and polluted environments to realize different scientific purposes.

The CPC UF-02M was compared with the commercial SMPS TSI3936 under ambient conditions. The measured number concentrations were comparable with 5\% accuracy. Only, during new particle formation the CPC measured higher particle number concentrations than the SMPS did. It can be explained by the fact that the modernized CPC has a smaller cut-size compared with the SMPS. Increase in the number concentration of new formatted nanoparticles was registered with the CPC UF-02M earlier than with the SMPS. Thus, the application of the CPC UF-02M in atmospheric physics gives possibilities for better understanding of the nanoparticle dynamical processes.

\section{References}

[1] L. Metnieks and L.W. Pollak, Introduction for Use of Photo-Electric Condensation Nucleus Counters (School of Cosmic Physics, Dublin Institute of Advanced Studies, 1959).

[2] G.J. Sem, Design and performance characteristics of three continuous-flow condensation particle counters: a summary, Atmos. Res. 62, 267-294 (2002).

[3] R. Mavliev, Turbulent mixing condensation nucleus counter, Atmos. Res. 62, 302-314 (2002).

[4] J. Wang, V.F. McNeill, D.R. Collins, and R.C. Flagan, Fast mixing condensation nucleus counter: application to rapid scanning differential mobility analyzer measurements, Aerosol Sci. Technol. 36: 678-689 (2002).

[5] F.R. Quant, R. Caldow, G.J. Sem, and T.J. Addison, Performance of condensation particle counters with three continuous-flow designs, J. Aerosol Sci. 23, S405-S408 (1992).

[6] S. Mertes, F. Schröder, and A. Wiedensohler, The particle detection efficiency curve of the TSI-3010 $\mathrm{CPC}$ as a function of the temperature difference between saturator and condenser, Aerosol Sci. Technol. 23, 257-261 (1995).

[7] P.H. McMurry, The history of CPCs, Aerosol Sci. Technol. 33, 297-322 (2000).

[8] K. Hämeri, I.K. Koponen, P.P. Aalto, and M. Kulmala, The particle detection efficiency of the TSI3007 condensation particle counter, J. Aerosol Sci. 33, 1463-1469 (2002).

[9] G. Mordas, H.E. Manninen, T. Petäjä, P.P. Aalto, K. Hämeri, and M. Kulmala, On operation of the ultra-fine water-based CPC TSI3786 and comparison with other TSI models (TSI3776, TSI3772, TSI3025, TSI3010, TSI3007), Aerosol Sci. Technol. 42, 152-158 (2008).

[10]S.V. Hering and M.R. Stolzenburg, A method for particle size amplification by water condensation in a laminar, thermally diffusive flow, Aerosol Sci. Technol. 39, 428-436 (2005).

[11]S.V. Hering, M.R. Stolzenburg, F.R. Quant, D.R. Oberreit, and P.B. Keady, A laminar-flow, water-based condensation particle counter (WCPC), Aerosol Sci. Technol. 39, 659-672 (2005).

[12] W. Liu, S.L. Kaufman, B.L. Osmondson, G.J. Sem, F.R. Quant, and D.R. Oberreit, Water-based condensation particle counters for environmental monitoring of ultrafine particles, J. Air Waste Manage. 56, 444-455 (2006).

[13]T. Petäjä, G. Mordas, H. Manninen, P.P. Aalto, K. Hämeri, and M. Kulmala, Detection efficiency of water-based TSI condensation particle counter 3785, Aerosol Sci. Technol. 40, 1090-1097 (2006).

[14] G. Mordas, T. Petäjä, and V. Ulevičius, Optimisation of the operation regimes for the water-based 
condensation particle counter, Lith. J. Phys. 52(3), 253-260 (2012).

[15] M.R. Stoltzenburg and P.H. McMurry, An ultrafine aerosol condensation nucleus counter, Aerosol Sci. Technol. 14, 48-65 (1991).

[16] A. Asmi, M. Collaud Coen, J.A. Ogren, E. Andrews, P. Sheridan, A. Jefferson, E. Weingartner, U. Baltensperger, N. Bukowiecki, H. Lihavainen, N. Kivekäs, E. Asmi, P.P. Aalto, M. Kulmala, A. Wiedensohler, W. Birmili, A. Hamed, C. O’Dowd, S.G. Jennings, R. Weller, H. Flentje, A. Mari Fjaeraa, M. Fiebig, C. Lund Myhre, A.G. Hallar, and P. Laj, Aerosol decadal trends - Part 2: In-situ aerosol particle number concentrations at GAW and ACTRIS stations, Atmos. Chem. Phys. Discuss. 12, 20849-20899 (2012).

[17] C. Reche, X. Querol, A. Alastuey, M. Viana, J. Pey, T.Moreno, S. Rodríguez, Y. González, R. FernándezCamacho, A.M. Sánchez de la Campa, J. de la Rosa, M. Dall'Osto, A.S.H. Prévôt, C. Hueglin, R.M. Harrison, and P. Quincey, New considerations for PM, Black Carbon and particle number concentration for air quality monitoring across different European cities, Atmos. Chem. Phys. 11, 6207-6227 (2011).

[18]H.G. Scheibel and J. Porstendörfer, Generation of monodisperse $\mathrm{Ag}$ - and $\mathrm{NaCl}$-aerosols with par- ticle diameters between 2 and $300 \mathrm{~nm}$, J. Aerosol Sci. 14(2), 113-126 (1983).

[19] A. Wiedensohler, D. Orsini, D.S. Covert, D. Coffmann, W. Cantrell, M. Havlicek, F.J. Brechtel, L.M. Russell, R.J. Weber, J. Gras, J.G. Hudson, and M. Litchy, Intercomparison study of the sizedependent counting efficiency of 26 condensation particle counters, Aerosol Sci. Technol. 27, 224242 (1997).

[20] TSI Inc, Model 3936 SMPS (Scanning Mobility Particle Sizer), Operation and Service Manual, P/N 1933796, Revision H (TSI press, Massachusetts, 2003).

[21] V. Ulevičius, M. Kulmala, G. Mordas, V. Matulevičius, V. Grigoraitis, K. Hämeri, and P. Aalto, Method and apparatus for increasing the size of small particles, EU Patent No. EP 1702205 (2006).

[22] V. Ulevičius, S. Byčenkienè, V. Remeikis, A. Garbaras, S. Kecorius, J. Andriejauskiene, D. Jasinevičienė, and G. Mocnik. Characterisation of pollution events in the East Baltic region affected by regional biomass fire emissions. Atm. Research 98(2-4), 190-200 (2010).

[23] K. Plauškaitè, V. Ulevičius, N. Špirkauskaitè, S. Byčenkienè, T. Zielinski, T. Petelski, and A. Ponczkowska. Observation of new particle formation events in the south-eastern Baltic sea, Oceanologia 52(1), 53-75 (2010).

\title{
KONDENSACINIO DALELIU SKAITIKLIO UF-02M PATIKIMUMO VERTINIMAS LABORATORIJOS IR APLINKOS SĄLYGOMIS
}

\author{
G. Mordas, V. Ulevičius, K. Plauškaite, N. Prokopčiuk \\ Valstybinis moksliniu tyrimu institutas Fiziniu ir technologijos moksly centras, Vilnius, Lietuva
}

\section{Santrauka}

Straipsnyje pateikiami patobulinto kondensacinio dalelių skaitiklio UF-02M eksperimentinių tyrimų duomenys. Nustatyti pagrindiniai skaitiklio veikimo parametrai (kondensacinès kameros ir garintuvo temperatūros, aerozolio ir butanolio garu srautai). Ivertinta aerozolio dalelių registravimo efektyvumo priklausomybė nuo dalelių dydžio. Taikant trijų laisvų parametrų funkciją ìvertintas registravimo efektyvumo ribinis dydis $\left(\mathrm{D}_{50 \%}\right)$, kuris yra $4,35 \mathrm{~nm}$. Ivertintas aerozolio dalelių skaičiavimo efektyvumas naudojant $20 \mathrm{~nm}$ dydžio sidabro dalelès. Nustatytos mažiausios ir didžiausios registruojamos dalelių skaitinès koncentracijos: atitinkamai 0,003 ir $150000 \mathrm{~cm}^{-3}$. Atliktas kondensacinio dalelių skaitiklio UF-02M testavimas aplinkos sąlygomis matuojant Baltijos jūros pakrantès aerozoli kartu su komerciniu aerozolio dalelių spektrometru TSI3936. Palyginimo rezultatai parode, kad matuojamos daleliu koncentracijos sutampa 5 \% tikslumu. Tačiau UF-02M registravo didesnes koncentracijas naujų dalelių susidarymo metu. Tai paaiškinama tuo, kad skaitiklio UF-02M registravimo efektyvumo ribinis dydis yra mažesnis negu komercinio spektrometro TSI3936. Tikimès, kad patobulinto kondensacinio dalelių skaitiklio UF-02M taikymas atmosferos fizikos tyrimams suteiks galimybę sukaupti tikslesnių ir vertingų žinių apie aerozolio nanometrinių dalelių dinaminius procesus. 